\title{
ANALYSIS OF THE IMPLEMENTATION OF FINANCIAL ACCOUNTING STANDARDS WITHOUT PUBLIC ACCOUNTABILITY (SAK ETAP) ON THE PRESENTATION OF GIRIREJO VILLAGE UNIT'S COOPERATIVE FINANCIAL STATEMENTS
}

\author{
Muhammad Rasyid ${ }^{*}$ \\ ${ }^{1}$ Affiliation Universitas Tidar \\ E-mail: ${ }^{1)}$ muhamadrasyid40211@gmail.com
}

\begin{abstract}
The Indonesian Institute of Accountants (IAI) publishes Financial Accounting Standards for Entities Without Accountability so that entities that have not gone public can provide accurate financial reports (SAK ETAP). In reality, many cooperatives still do not use SAK ETAP in the preparation of their financial statements. The purpose of this research is to identify how the Girirejo Village Unit Cooperative's financial statements should be presented under the Financial Accounting Standards for Entities Without Public Accountability (SAK ETAP). This study uses a qualitative approach to conduct a comparative study. Methods of collecting data by interview. The method employed is a comparison of the Financial Accounting Standards of Entities Without Public Accountability (SAK ETAP) with the presentation of Girirejo's Village Unit Cooperative financial statements. In essence, SAK ETAP has been adopted in Girirejo's Village Unit Cooperative financial accounts. The financial accounts of Girirejo Village Unit Cooperative demonstrate that the balance sheet, income statement, equity report, cash flow statement, and notes to financial statements have all been presented; nevertheless, several items such as inventories and investments, tax obligations, and tax expenses have not been recorded.
\end{abstract}

Keywords: Financial Accounting Standards of Entities Without Public Accountability (SAK ETAP), Financial Report, Girirejo Village Unit Cooperative

\section{INTRODUCTION}

It is necessary for a corporate entity to have an information system in order to manage or be responsible for its operational activities. System reports can be used for planning, evaluation, performance appraisal, and accountability to stakeholders. The system can generate reports that can be utilized for these purposes. External parties require information about operational actions and obligations, and accounting serves as an information system that provides this information. Diverse sorts of business entities can make use of accounting information that is neutral in nature and has the same aim in financial reporting because it is neutral in nature. Despite the fact that cooperative business entities are slightly different from other types of businesses, the information offered in the financial statements is useful to those who are interested in learning more about the organization. As such, cooperative financial reporting is in the form of accountability for business actions to other parties, such as cooperative members or creditors who have a stake in a cooperative. 
The cooperative's financial report is comprised of the following: (1) a balance sheet that details the amount of assets handled, the cooperative's commitments to creditors, and the cooperative's net value. (2) Determination of business results gives information about the outcomes of company activities and cooperative management over a certain time period. (3) Cash flow statements, which detail the inflows and payments of cash over a specified time period. (4) Reports on member economic improvement, including information on the amount of benefit obtained by the cooperative. (5) Financial statements include notes that contain information about accounting policies and other disclosures. Financial statements must adhere to particular criteria in order to be relied upon and compared to prior period financial statements or financial statements of other business organizations. Reports must be carefully written and convey the same message to stakeholders, as financial statements play a critical role in regulating corporate continuity. As a result, financial accounting standard that governs the presentation of business entities' financial statements is needed.

In Indonesia, four pillars of accounting standards govern the financial reporting of various types of commercial enterprises. The four pillars are generally accepted financial accounting standards (hereinafter referred to as SAK), SAK for Entities Without Public Accountability (hereinafter referred to as SAK ETAP), shariah financial accounting standards (SAK Syariah), and government accounting standards (hereinafter referred to as SAP). SAK that is applicable to the interests of corporations or corporate entities that are accountable to the public. SAK will be difficult to apply to Micro, Small and Medium-Sized Enterprises (MSMEs) and cooperatives since fundamental and accounting skills are still lacking and the type of business remains simple. The Indonesian Institute of Accountants (IAI) released Financial Accounting Standards Entities Without Public Accountability (SAK ETAP) in 2009 to address the financial reporting demands of cooperative business entities and micro, small, and medium-sized enterprises (MSMEs). For commercial entities that lack significant accountability, the public SAK ETAP is appropriate. Because cooperative business entities do not have significant financial reporting obligations, they can quickly produce their financial reports using SAK ETAP. Cooperatives must manage operational activities properly in order to continue their development and progress. Besides that, SAK ETAP becomes an expectation to be able to improve the quality of MSME financial statements to be better than currently available (Rudiantoro \& Siregar, 2012; Warsono et al., 2010).

Professional cooperative management necessitates an effective accountability structure that can be depended upon for planning, managing, and controlling, as well as decisionmaking. Financial statements are one of the tools required for decision making. As a consequence, cooperatives must prepare financial accounts in compliance with the requirements of SAK ETAP. Through cooperatives, it can give employment possibilities for those in need, so benefiting the economy. One of the issues that frequently arises in cooperatives is the inadequacy of financial reports that are not sufficiently structured and uniform. Financial statements, according to Baridwan (2004), are "summaries of financial transactions that occurred during the fiscal year in question." Furthermore, SAK ETAP is intended for entities that (a) do not have significant public accountability; and (b) publish a general-purpose financial statement for external users (Narsa, 2017). 


\section{JOURNAL OF MANAGEMENT, ACCOUNTING, GENERAL FINANCE AND INTERNATIONAL ECONOMIC ISSUES (MARGINAL) \\ VOLUME 1 ISSUE 2 (2022)}

When financial reports are prepared, an accounting standard that is tailored to the demands of cooperative actors is used, namely SAK ETAP (Financial Accounting Standards for Entities Without Public Accountability). SAK ETAP is used for non-public companies, such as cooperatives and SMEs. SAK ETAP is expected to enable cooperatives of small and medium-sized firms to maintain bookkeeping, particularly in the presentation of financial statements, making it simpler to obtain financial support from the government and financial institutions such as banks in the future. The Girirejo Village Unit Cooperative is a savings and loan cooperative. The researcher picked the Girirejo Village Unit Cooperative as the subject of her research since it has been operating for a long period of time and the majority of its members are residents of Girirejo Village. The researchers discovered that cooperatives have not fully applied SAK ETAP when presenting financial statements. This is demonstrated by the existence of posts that are inconsistent with SAK ETAP, such as the absence of tax liability posts. With this background in mind, the researcher is interested in performing a study entitle "Analysis of the Application of Financial Accounting Standards for Entities Without Public Accountability (SAK ETAP) in the Presentation of the Girirejo Village Unit Cooperative's Financial Statements."

\section{LITERATURE REVIEW}

\subsection{Cooperative}

According to the Indonesian Accounting Association (IAI) in the book "Financial Accounting Standards" (SAK no.27) of 2004, cooperatives are business entities that organize the utilization and utilization of economic resources of its members based on cooperative principles and economic business principles to improve living standards of members in particular and the community in general, thus cooperatives are a people's economic movement and guide of the national economy (Hendar, 2010). In Article 1 of Law Number 25 of 1992 concerning "cooperatives" it is emphasized that cooperatives are business entities consisting of individuals or legal entities based on activities based on cooperative principles and people's economic movements based on kinship. The key is the understanding of cooperatives which consists of elements, namely a collection of people, voluntary, has the same economic objectives, democratically controlled organizations, provides equitable capital, and obtains and receives equitable benefits.

\subsection{Financial Accounting Standards for Entities Without Public Accountability (SAK ETAP)}

SAK ETAP explains that the criteria for entities that are included in entities without public accountability (IAI, 2009), include:

1. Does not have significant public accountability. An entity is said to have significant accountability if:

An entity has submitted a statement or is in the process of submitting a statement to the capital market authority (BAPEPAM - LK) or other regulators regarding the issuance of securities in the capital market. Therefore, Bapepam itself has issued Circular (SE) Bapepam - LK No. SE-06/BL/2010 concerning Prohibition of Use of SAK ETAP for Capital Market Institutions, including Issuers, Public Companies, Investment Managers, Securities, Insurance Institutions, mutual funds, and collective 
investment contracts. An entity controls assets in a fiduciary capacity for a large group of people, such as banks, insurance entities, brokers and/or securities traders, pension funds, mutual funds, and investment banks.

2. Not issuing general purpose financial reports to external users.

\subsection{Scope of SAK ETAP}

According to Tuti (2009), the accounting policies of SAK - ETAP are in some aspects that lighter than PSAK, therefore there are several transitional provisions in SAK - ETAP which are quite strict, namely:

a. In Chapter 29, for example, it is stated that in the first year of application of SAKETAP, namely January 1, 2011 Entities that meet the requirements for implementing SAK-ETAP can prepare financial statements not based on SAK-ETAP, but based on non-ETAP PSAK which is applied consistently. Entities are not allowed to apply SAK-ETAP further in the preparation of subsequent financial statements.

b. As of January 1, 2011, companies that meet the definition of an Entity Without Public Accountability must choose whether to prepare financial statements using PSAK or switch to using SAK-ETAP.

c. An entity that prepares financial statements based on SAK-ETAP then does not meet the requirements of entities that may use SAK-ETAP, then the entity is not allowed to prepare reports based on SAK-ETAP. For example, a medium-sized company decided to use SAK - ETAP in 2011, but was registered as a public company the following year. Entities are required to prepare financial statements based on non-ETAP PSAK and are not allowed to apply this SAK-ETAP again.

d. Entities that used to use non-ETAP PSAK in preparing their financial statements can use SAK-ETAP in preparing their financial statements if they meet the requirements of entities that can use SAK-ETAP. From the statement above, it is clearly implied that the small and medium enterprises referred to by SAK-ETAP are non-listed small and medium enterprises or entities that are not listed on the stock exchange. This means that there are two different accounting standards that are used as a reference in the preparation and financial reporting. That is, there will also be measurement and disclosure standards that are different from each of these accounting standards. On the one hand there is SAK-ETAP which is specifically intended for small and mediumsized entities that are not registered, on the other hand there is general SAK, in this case PSAK which is intended for other entities, including SMEs.

\subsection{Presentation of Financial Statements in accordance with SAK ETAP}

Harahap (2009) explains that financial statements provide a snapshot of a company's financial health and performance at a given point in time. Financial statements also a way for companies to communicate important financial information to the outside world (Hunt et al., 2011; Kieso et al., 2019).

Moreover, financial accounting standards (SAK) are a framework for preparing financial statements so that financial statements are presented in a consistent manner (Wuwungan, 2016). A company activity's accounting is a way to identify, record, and report economic information that can be used as a guide for making management decisions (Pangerapan, 2013). 


\section{JOURNAL OF MANAGEMENT, ACCOUNTING, GENERAL FINANCE AND INTERNATIONAL ECONOMIC ISSUES (MARGINAL) \\ VOLUME 1 ISSUE 2 (2022)}

According to Soemarso (2008), businesses that prepare financial statements in conformity with SAK-ETAP must include explicit and unconditional statements in the notes to the financial statements attesting to such compliance. An entity's ability to continue as a going concern is examined by management while preparing financial statements using SAKETAP (Amin, 2002). As part of the assessment of whether or not the company can continue as a going concern, the company must disclose any material uncertainty that its management is aware of. This must be declared, along with the foundation for the financial statement's production and the reasons for the entity's lack of continuity of business, when a company does not prepare financial statements on a going concern basis.

\section{RESEARCH METHOD}

The research technique used in this research is comparative. According to Sugiyono, (2015) comparative research is a comparative study. In this study, the authors will compare the financial statements made by the Girirejo Village Unit Cooperative with the Financial Accounting Standards for Entities Without Public Accountability (SAK ETAP). The location of the research conducted in this article is in Girirejo Village, Tegalrejo District, Magelang Regency, Central Java Province.

In this paper, primary data and secondary data are used. Primary data is the data obtained directly by means of interviews with those authorized to provide information are used. Meanwhile, secondary data obtained by looking for references that have to do with this research.

\section{RESULT AND DISCUSSION}

Based on the presentation of the financial statements of Girirejo Village Unit Cooperative (KUD) has presented the following statement.

1) Balance

The balance sheet at the Girirejo Village Unit Cooperative (KUD) presents assets, liabilities, and equity. This is in accordance with the rules in SAK ETAP which presents assets, liabilities, and equity. In the presentation of assets there are two items that are included in the "profit sharing" criteria, namely inventory items and investment properties and in the presentation of liabilities there is one item that meets the "profit sharing" criteria, namely the tax liability item that has not been submitted by KUD Girirejo.

2) Income Statement

The income statement at the Girirejo Village Unit Cooperative is called a business calculation report. Business calculation report is a report that shows all income and expenses of the Girirejo Village Unit Cooperative in one period. However, in its presentation, there is one post that meets the criteria for "profit sharing" according to SAK ETAP, namely the post of tax burden that has not been presented by the Girirejo Village Unit Cooperative.

3) Equity Change Report

Equity change report is a report that shows changes in the equity of the Girirejo Village Unit Cooperative which describes an increase or decrease in assets or net worth during the reporting period. This is in accordance with the provisions of SAK ETAP.

4) Cash Flow Statement 
Cash flow report is a report showing cash receipts and disbursements of the Girirejo Village Unit Cooperative during a certain period. The Girirejo Village Unit Cooperative has classified cash flows into 3, namely: cash flows from operating activities, cash flows from investing activities and cash flows from financing activities. This is also in accordance with the provisions according to SAK ETAP.

5) Notes to Financial Statements

The notes to the financial statements contain an explanation of the general description of the Girirejo Village Unit Cooperative, an overview of accounting policies, explanations of financial statement items and other important information. This is also in accordance with the provisions according to SAK ETAP.

\section{CONCLUSION}

Based on the results of the analysis that has been done, it can be concluded that:

1. In general, the Girirejo Village Unit Cooperative has adopted the SAK ETAP program, according to the cooperative. In order to demonstrate conformity, the firm has submitted comprehensive financial statements that comprise a balance sheet, income statement, statement of changes in equity, cash flow statement, and notes to financial statements.

2. In presenting the financial statements of the Girirejo Village Unit Cooperative, there are several items that are not fully in accordance with the Financial Accounting Standards for Entities Without Public Accountability (SAK ETAP), namely inventory items and investment property items and there are items that are not presented, namely tax obligations and tax burdens.

\section{REFERENCES}

Amin, W. (2002). Akuntansi Untuk Koperasi. PT Rineka Cipta.

Baridwan, Z. (2004). Akuntansi Menengah. BPFE.

Harahap, S. S. (2009). Analisis Kritis atas Laporan Keuangan Edisi Ke satu. Jakarta: PT. Raja Grafindo Persada.

Hendar. (2010). Manajemen Perusahaan Koperasi. Jakarta: Erlangga.

Hunt, M. F., Kieso, D. E., Weygandt, J. J., \& Warfield, T. D. (2011). Intermediate Accounting, Problem Solving Survival Guide (Vol. 1). John Wiley \& Sons.

IAI. (2009). Standar Akuntansi Keuangan Entitas Tanpa Akuntabilitas Publik (SAK ETAP). Jakarta: Dewan Standar Akuntansi Keuangan Ikatan Akuntan Indonesia.

Kieso, D. E., Weygandt, J. J., Warfield, T. D., Wiecek, I. M., \& McConomy, B. J. (2019). Intermediate Accounting, Volume 2. John Wiley \& Sons.

Narsa, N. P. D. R. H. (2017). SAK-ETAP Sebagai Solusi Overload Standar Akuntansi Bagi Usaha Mikro, Kecil, Menengah, dan Koperasi. EKUITAS (Jurnal Ekonomi Dan Keuangan), 1(1), 44-65.

Pangerapan, O. R. (2013). Analisis Perlakuan Akuntansi Untuk Website Pada PT. Bank Sulut (Persero) Manado. Jurnal EMBA: Jurnal Riset Ekonomi, Manajemen, Bisnis Dan Akuntansi, 1(3). 


\section{JOURNAL OF MANAGEMENT, ACCOUNTING, GENERAL \\ FINANCE AND INTERNATIONAL ECONOMIC ISSUES \\ (MARGINAL) \\ VOLUME 1 ISSUE 2 (2022)}

Rudiantoro, R., \& Siregar, S. V. (2012). Kualitas laporan keuangan umkm serta prospek implementasi SAK ETAP. Jurnal Akuntansi Dan Keuangan Indonesia, 9(1), 1-21.

Soemarso, S. . R. (2008). Koperasi : Suatu Pengantar. Salemba Empat.

Sugiyono. (2015). Metode penelitian pendidikan. In Jakarta: mitra wacana merdeka (pp. 286-288).

Tuti, T. (2009). Akuntansi untuk koperasi dan UKM. Cetakan Pertama: Salemba Empat, Jakarta.

Warsono, S., Murti, E., Ridha, A., \& Darmawan, A. (2010). Akuntansi UMKM ternyata mudah dipahami dan dipraktikkan. Asgard Chapter Yogyakarta.

Wuwungan, J. Y. S. (2016). Analisis penerapan standar akuntansi keuangan entitas tanpa akuntabilitas publik atas persediaan pada apotik uno medika. Jurnal EMBA: Jurnal Riset Ekonomi, Manajemen, Bisnis Dan Akuntansi, 3(4). 
